\title{
Stimulation of wound healing process through ROS/RNS signals indirectly generated by N2/Ar micro-plasma - in vitro and in vivo studies
}

- Ngo Thi Minh Hien ${ }^{1}$

- Huynh Quang Linh ${ }^{1}$

- Liao Jiunn Der ${ }^{2}$

- Nguyen Nhu Son Thuy ${ }^{1}$

${ }^{1}$ Ho Chi Minh city University of Technology, VNU-HCM

${ }^{2}$ National Cheng Kung University

(Manuscript Received on August 01st, 2015, Manuscript Revised August 27th, 2015)

\section{ABSTRACT:}

In this work, non-thermal N2/Ar micro-plasma was applied to fibroblast cells and second degree burn in mice to investigate the bio-safety and bioefficiency of micro-plasma device for studying wound healing process. The chosen parameters of the device were the addition of $0.5 \%$ N2 in argon plasma and RF supplied power of $17 \mathrm{~W}$ and 13 $W$ in vitro and in vivo studies, respectively. Firstly, micro-plasma was applied to fibroblast cells and the induced biological effect was studied in vitro. The result showed that cells number increased three folds for plasma exposure time of 5 or $10 \mathrm{sec}$, followed by

cell culture for $48 \mathrm{hrs}$. The cell coverage rate rose $20 \%$ for the same plasma exposure time, followed by cell culture for 6 or 12 hrs. Secondly, micro-plasma was applied to the second degree burn wound mice, followed by related ex vivo and in vivo assessments. For the former, $0.5 \% \quad \mathrm{~N} 2 / \mathrm{Ar}$ micro-plasma was competent to generate ROS/RNS signals for advancing healing process by the increase of ROS/RNS concentration around the plasma-exposed wound bed. The induced effect is most probably correlated with the angiogenesis and epithelialization processes of the burn wound on mice.

Key words: Non-thermal micro-plasma, fibroblast cells, proliferation, migration, second degree burn wound, ROS/RNS signals, wound healing.

\section{INTRODUCTION}

Recently, plasma therapy has attracted widespread interested, the literature indicates that ROS (reactive oxygen species)/RNS (reactive nitrogen species) signals indirectly generated by micro-plasma exposure have a positive effect to the wound healing $[1,2]$. Non-thermal atmospheric micro-plasma devices with an operational heat close to body temperature have received considerable attention due to their great potential for a variety of biomedical applications, such as heat-free bacteria inactivation and sterilization [4], in vitro and in vivo blood coagulation [5], acute and chronic wound healing [6], and regeneration of damaged tissues [7]. 
When $\mathrm{N}$, O-containing plasma species are exposed to target substances, neutral atoms and molecules and active short-or long-lived species, including $\mathrm{O}_{3}, \mathrm{NO}, \mathrm{OH}$ radicals, singlet $\mathrm{O}_{2}{ }^{1} \Delta \mathrm{g}$, and super oxide radicals [5, 8, 9] will presumably play major roles in the interactions that occur at the plasma/target interface.

Via oxidation and nitrosation processes, nitrite and nitrate, which are RNS form in the cytoplasm. Recent studies have shown that the biological functions of ROS/RNS signals through the nitrate-nitrite-NO pathway are of great importance. The reduction of nitrite, which forms the NO radical, may alter protein signaling and thereafter contribute to cell responses. The induced signaling may act like a regulator for vascular angiogenesis and tissue epithelialization in processes such as wound healing.

Fibroblast cells play a guiding role in the second phase of wound healing that occurs $2 \sim 10$ days after injury, and is usually characterized by cellular proliferation and migration of different cell types. Burn injuries are a major public health problem and cause more severe physiological stress than other traumas. First-degree (superficial) burns usually heal with minimal scarring.

However, there are no optimal treatments for second-degree (partial-thickness) burn. Second-degree burns can be superficial, reaching the epidermis and superficial dermis, or deep, extending to the deepest layer of the dermis. The conversion of the second-degree burn wounds into third-degree (full-thickness) burns remains a vital clinical challenge, this conversion which takes long time to heal and results in the formation of hypertrophic scars, delay the healing process. Therefore, this study focus on the effect of micro-plasma exposed to fibroblast cells and second degree burn wound in mice to reveal the efficiency of micro-plasma device for biomedical applications.

In this study, plasma plume temperature and RPS in $\mathrm{N}_{2} / \mathrm{Ar}$ micro-plasma were first measured, and then the characterized micro-plasma was applied to fibroblast cells (L929) in a medium.

Several techniques were used for the assessment of cell functions after plasma exposure cells, as follows: mitochondrial function (MTS assay) for cell proliferation, reactive oxygen species (ROS) detection, and cell coverage model in vitro for the tendency of accelerating cells migration. The importance of this work is that it aims to interpret the role of RPS, and thereafter ROS, in a cell-containing medium for the stimulation of fibroblast cells. In vivo study, several techniques are commonly employed for the assessment of burn wound healing after plasma exposure. Wound area reduction measurement, an ex-vivo experiment for the detection of ROS/RNS concentrations in the tissue lysate were performed.

\section{MATERIALS AND METHODS}

\subsection{Micro-plasma diagnosis and Reactive plasma species kinetics}

The micro-plasma device used in vitro study contained a quartz tube as the gas channel and a dielectric layer with an outer diameter of $2 \mathrm{~mm}$. At the center of the quartz tube, a stainless steel capillary tube (with a diameter of $0.2 \mathrm{~mm}$, fixed by a perforated Teflon fitting) was used as the inner electrode as well as the $\mathrm{N}_{2}$ or $\mathrm{O}_{2}$ feeding tube.

The flow rate of working and additional gas was controlled by Mass flow control (MKS instruments, USA). A copper chip was used as the outer electrode, and this was connected to a generator.

Based on the basic principle structure that used to expose the fibroblast cells, the microplasma for in vivo study has modified not only 
outside shape but also the components inside, such as the shorter quartz tube, the gas chamber, the copper electrode shape, etc. to make this device more convenience and efficiency to treatment the mice (Figure 1)

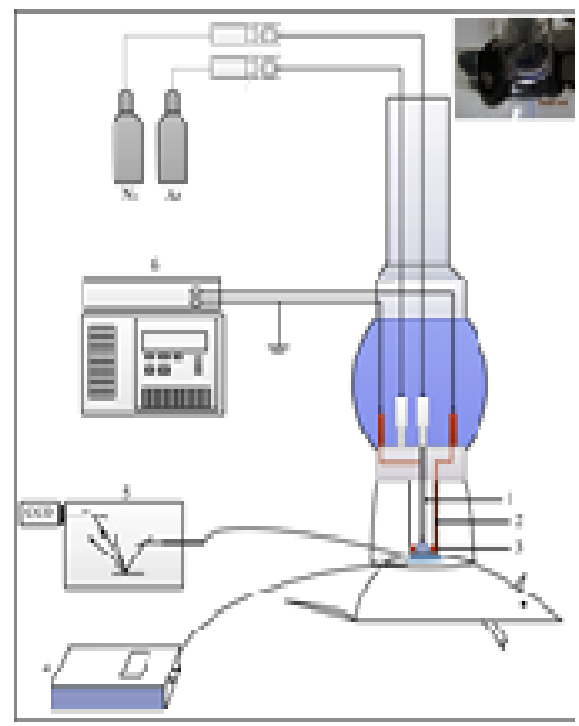

Figure 1: Experimental set up of N2/Ar microplasma exposure to the burn wound mice: 1 . hollow stainless steel inner electrode, 2. dielectric quartz tube, 3. outer copper electrode, 4. fiber optic thermometer, 5. OES device, 6. radio frequency power supply, and 7. mass flow controller.

Plasma plume temperature

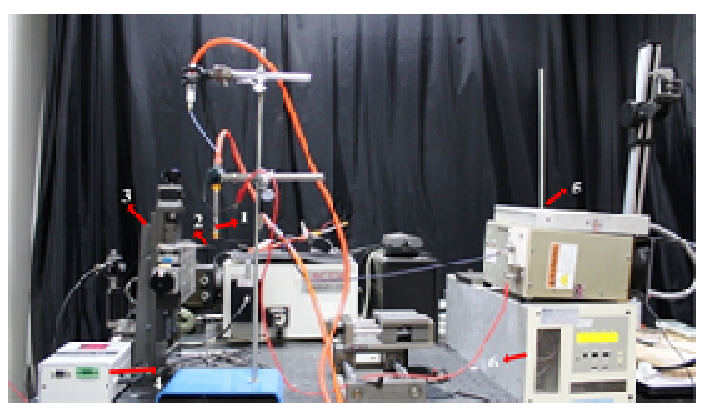

Figure 2: Experiment set up for measuring plasma plume temperature of plasma jet device, that consist of the following components: 1. Micro-plasma, 2. Optical fiber, 3. X-Y coordinated table, 4. Fiber optic thermometer, 5. Matching network, 6. Supplied power.
Plasma plume temperature was estimated using a fiber optic thermometer (Luxtron 812, Santa Clara, USA). The fiber was placed on an $\mathrm{X}-\mathrm{Y}$ coordinated table and the distance from the fiber to micro-plasma jet nozzle was $\approx 12 \mathrm{~mm}$ for in vitro (Figure 2 ) and $\approx 4 \mathrm{~mm}$ for in vivo study

\subsection{RPS measuring using Optical Emission Spectroscopy}

RPS such as $\mathrm{NO}, \mathrm{OH}, \mathrm{O}$ were analyzed using Optical Emission Spectroscopy (OES, SpectraPro 2300i, Acton Research Corp., Massachusetts, USA) in Figure 3. The optical emission spectra were taken along the axis of micro-plasma jet and recorded in the range of 200 1100 nm. The emitted light was then focused by optical fibers into the entrance slit of single monochromater (SpectraPro 2300i, Acton Ltd, MA, USA) equipped with a CCD detector $(1340 \times 100$ pixels $)$.

The resolution of the collected spectra was 1200 grooves per millimeter with the slit width of $\approx 0.1 \mathrm{~nm}$. Two gratings, 200 500 (1200 g.mm $\left.{ }^{-1}\right)$ and $500 \sim 1100 \mathrm{~nm}\left(1200 \mathrm{~g} \cdot \mathrm{mm}^{-1}\right)$, were utilized to estimate the composition of RPS before interacting with the test cells and mice

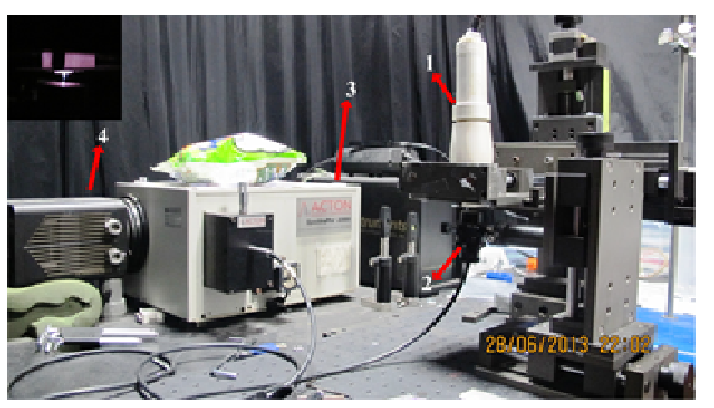

Figure 3: Experiment set up for measuring reactive plasma species that consist of the following components: 1.Micro-plasma, 2. Optical fiber, 3. Monochromater, 4. CCD.

ROS in plasma-exposed medium

RPS interacting with the medium containing the plasma-exposed cells was measured using 2', 7'-dichlorodihydrofluorescein diacetate (DCHF- 
DA, Cayman chemicals). Before the experiments, DCHF-DA was directly dissolved in $0.1 \mathrm{M}$ $\mathrm{Na}_{2} \mathrm{CO}_{3}$ (or $5 \mathrm{mg} / \mathrm{ml}$, Sigma, St Louis, MO), and then immediately diluted with PBS $(\mathrm{pH}=7.2)$. Three kinds of cells $(\approx 100 \mu \mathrm{l}$ for each), the test cells, the test cells with $\mathrm{H}_{2} \mathrm{O}_{2}$ (the positive control), and the test cells exposed to $\mathrm{N}_{2} / \mathrm{Ar}$ micro-plasma, were transferred to 96 -well plates. After 5, 30, $60 \mathrm{~min}$ incubation at $37^{\circ} \mathrm{C}$ under 5\% $\mathrm{CO}_{2}$, the absorbance at $500 \mathrm{~nm}$ for these samples was analyzed using a microplate reader (Tecan, Group Ltd, Mannedorf, Switzerland).

Ex vivo experiment for ROS/RNS measurements in tissue lysate

The as-prepared DCHF- DA was stored on ice until use. Fresh DCHF-DA was prepared for each experiment and immediately used. Before plasma exposure, fresh DCHF-DA $(\approx 25 \mu \mathrm{M})$ was added to each well of 96-well plates and then exposed to $\mathrm{N}_{2} / \mathrm{Ar}$ micro-plasma for 30,60 , or 90 sec. Nitrite was measured using the Griess assay (Promega, Madison, MI, USA). The wound samples were first frozen in liquid nitrogen and then homogenized by a homogenizer (935C Cobb Place Blvd. Kennesaw, Georgia, USA) in $1 \mathrm{X}$ lysis buffer (Biochain Inst, Inc. Eureka Drive, Newark, CA, USA). The extracted tissue was cleared by centrifugation at $16,000 \mathrm{~g}$ for $20 \mathrm{~min}$ at $4{ }^{\circ} \mathrm{C}$ (Centrifuge 5415R, Hamburg, Germany) in Figure 4.

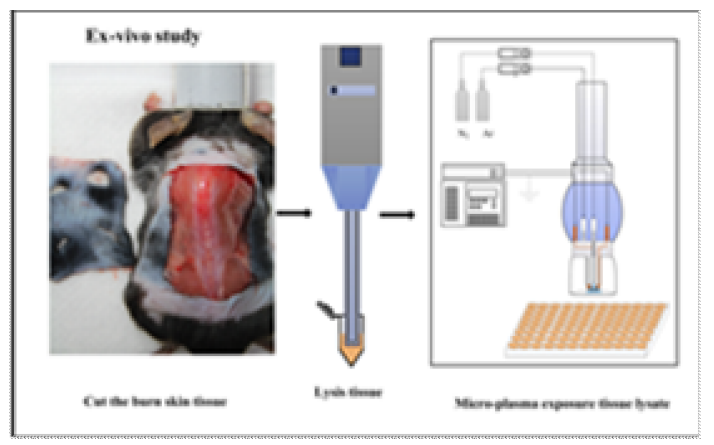

Figure 4: Ex-vivo study for ROS/RNS detection. The burn skin was cut, and lysis immediately by
Homogenizer, than the tissue lysate was exposed to micro-plasma.

\subsection{In vitro study of N2/Ar micro-plasma on fibroblast cell functions}

Cell proliferation and cell coverage tests

The test-cell viability with and without plasma exposure was assessed via MTS assay (CellTiter 96 AQueous One Solution Assay, Promega). In the experiments, plasma-exposed cells were cultured for 24 or $48 \mathrm{hrs}$ (two groups). The reagent AQueous One solution $(\approx 60 \mu \mathrm{l})$ was directly added to the culture wells containing both groups of cells. After $3 \mathrm{hrs}$ incubation at $37^{\circ} \mathrm{C}$ under $5 \% \mathrm{CO}_{2}$, the solution $(\approx 100 \mu \mathrm{l})$ in each culture well was transferred to 96-well plates (Nunc, Thermal Scientific, Denmark).

The absorbance at $492 \mathrm{~nm}$ for the solution in 96-well plates as measured with a standard microplate reader (Multiskan EX Labsystems, Finland). The quantity of formazan product in association with the intensity of absorbance was directly proportional to the number of cultured living cells. The migration ability of the plasmaexposed cells was assessed. The test cells were first exposed to $\mathrm{N}_{2} / \mathrm{Ar}$ micro-plasma for 5, 10, or $15 \mathrm{sec}$. The gaps filled by the test cells and plasma-exposed cells were observed using an optical microscope and evaluated with the WIMASIS image analysis software. Cell coverage tests were carried out every $3 \mathrm{hrs}$ until the gaps were fully covered.

\subsection{In vivo study in mice with burn wounds}

The experiment was conducted using C57BL/6JNarl male mice obtained from the National Laboratory Animal Center (Taipei, Taiwan). Ethics approval for the animal study was granted by the Institutional Animal Care and Use Committee (IACUC, Approval No. 101281) at the Laboratory Animal Center (Tainan, Taiwan). 
The mice were $6 \sim 8$ weeks old with a mean weight of $22.86 \pm 2 \mathrm{~g}$ at the beginning of experiments. The mice had free access to water and standard laboratory chow and were kept on a 12-hr light/dark cycle and maintained at room temperature $\left(23 \sim 24{ }^{\circ} \mathrm{C}\right)$. The mice were housed in separate boxes to protect them from bites and to avoid fighting after burn wounds were inflicted on their backs.

Initially, the mice were weighed and intramuscularly pre-anesthetized with $2 \%$ isoflurane inhalation (USP, Baxter, Guayama, USA). Thermal injuries, as shown in Figure 5, were made with a solid $\mathrm{Al}$ bar ( $5 \mathrm{~mm}$ in diameter) preheated in boiling water $\left(100^{\circ} \mathrm{C}\right)$ until thermal equilibrium was achieved. The $\mathrm{Al}$ bar surface temperature reached $69 \pm 2{ }^{\circ} \mathrm{C}$, as measured with a thermometer. The Al bar was maintained in contact with the animal skin on the shaved dorsal region of the mouse for $30 \mathrm{~s}$. The pressure exerted on the mice corresponded to the mass of the $\mathrm{Al}$ bar (41 g) used in the burn induction.

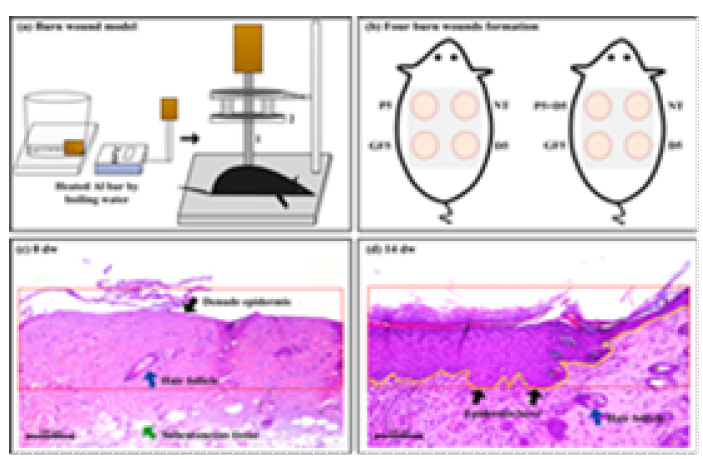

Figure 5: Formation of experimental burn wounds in mice. (a) Al bar (mark 1) at desired temperature clamped (marked 2) and lightly attached to target. (b) Four burn wounds created on back of one mouse immediately after burning process. Wound skin tissues on (c) 0 and (d) 14 day wound (dw) examined by $H \& E$ staining (200X).

\section{RESULTS AND DISCUSSION}

3.1. Plasma plume temperature and semi quantitative analysis of OES

At relatively low supplied powers (e.g., 13 W. $15 \mathrm{~W}, 17 \mathrm{~W}$ ) with the addition of $\mathrm{N}_{2}$, the plasma exhibited an average temperature of below $40{ }^{\circ} \mathrm{C}$. In these cases, the cells and the mice are presumably subjected to very minor effects due to the heat (Figures 6(a)).
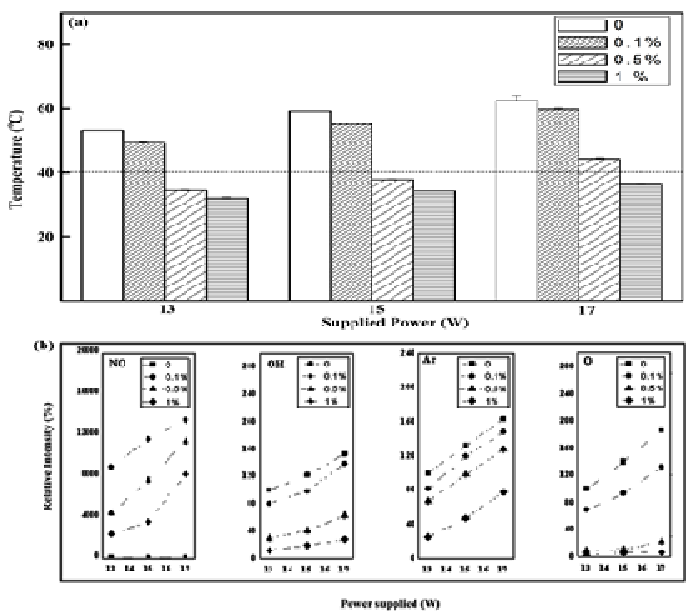

Figure 6: (a) and (b) Optical emission spectrum for $0.5 \% \mathrm{~N}_{2} / \mathrm{Ar}$ micro-plasma; (c) Relative intensity of individual reactive species with respect to $\mathrm{N}_{2}$ addition in Ar plasma. Error bars indicate the standard error of the mean for $n=6$ independent experiments.

In Figures 6(b), taking the OES spectra for $0.5 \% \mathrm{~N}_{2} / \mathrm{Ar}$ micro-plasma as examples, the presence of NO (237 nm), OH (306 nm), Ar-I $(750 \mathrm{~nm})$, and $\mathrm{O}(777 \mathrm{~nm})$ was obvious. The relative intensity of individual reactive species respect to $\mathrm{N}_{2}$ addition in Ar plasma has showed.

The emission intensities of $\mathrm{NO}, \mathrm{OH}, \mathrm{O}$, and Ar-I varied with the addition of $\mathrm{N}_{2}$ to the Ar plasma. The intensity of each plasma species from pure Ar plasma $\left(0 \% \mathrm{~N}_{2}\right)$ was taken as the reference.

\subsection{ROS in the plasma-exposed cell-containing medium}

Figure 7(a) shows the ROS levels in the 
plasma-exposed cell-containing medium after 5, 30 and $60 \mathrm{~min}$ incubation. Significant increases were found for the medium after plasma exposure for 5,10 , or $15 \mathrm{sec}$. In addition, the ROS levels in the medium roughly increased along with the plasma exposure time, as also compared with the medium under gas flow (Figure 7(b)).
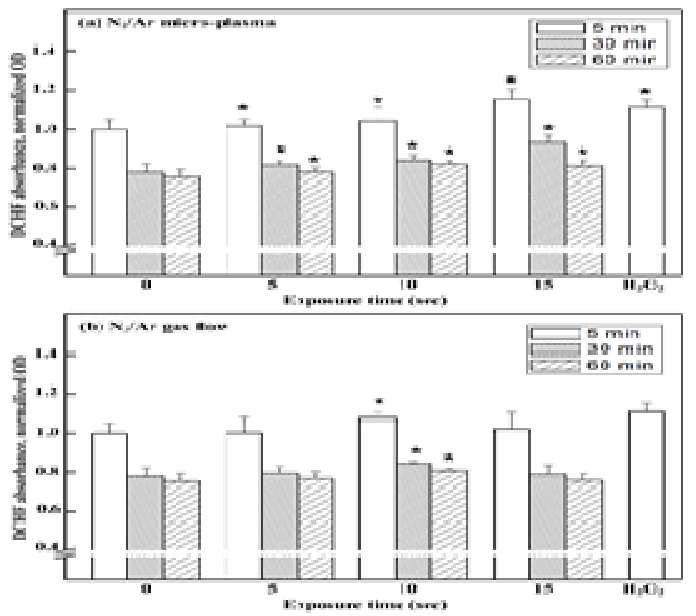

Figure 7: The (a) ROS content in the stimulated test cells medium after micro-plasma exposure, (b) ROS content in the stimulated test cells medium after gas flow exposure followed by culturing for 5, 30, $60 \mathrm{~min}$, respectively, All values were normalized to the values obtained with the control group. Error bars indicate the standard error of the mean for $n=6$ independent experiments.

\subsection{Stimulation of fibroblast cell proliferation and migration}

Fibroblast cell proliferation

Cell proliferation tests for the plasmaexposed cells (Figure 4-5(a)) with respect to the test cells $(0 \mathrm{sec})$ and those under gas flow (Figure 4-5(b)) were first carried out.

The proliferation of plasma-exposed cells $(5,10$, or $15 \mathrm{sec})$ was significantly enhanced $(\mathrm{p}<$ 0.05 or 0.01 ) after incubation for 24 or $48 \mathrm{hrs}$, as compared with untreated cells, with the increase being around three-fold.
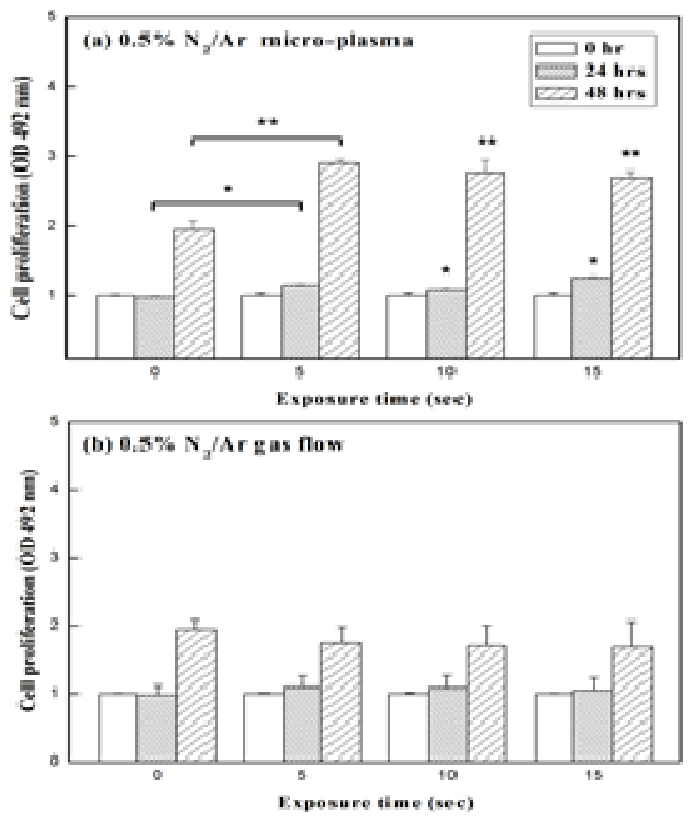

Figure 8: (a) The proliferation of the stimulated test cells after plasma exposure for 5,10 or $15 \mathrm{sec}$ and incubation for 24 or $48 \mathrm{hrs}$, as compared to (b) the control group. All values were normalized to the values obtained with the control group. Error bars indicate the standard error of the mean for $n=6$ independent experiments.

Cell coverage (Fibroblast cell migration)

Figure 9(a) shows images taken during the cell coverage tests for the plasma-exposed cells after incubation for 6 or 12 hrs. Figure 9(b) further examines the cells coverage rates in association with the cell migration ability.

Significant increases in cell migration were found for the plasma-exposed cells $(5,10$, or 15 sec) after incubation for 6 or 12 hrs $(p<0.05$ or 0.01 ), as compared with the untreated ones.

For example, there was an $\approx 80 \%$ increase in the cell coverage rate $(\approx 60 \%$ increase for the untreated cells) for the test cells after $10 \mathrm{sec}$ plasma exposure and 6 hrs incubation.

For a similar plasma exposure time and $12 \mathrm{hrs}$ incubation, an $\approx 98 \%$ increase of cells coverage 
rate $(\approx 87 \%$ increase for the untreated cells) was estimated.

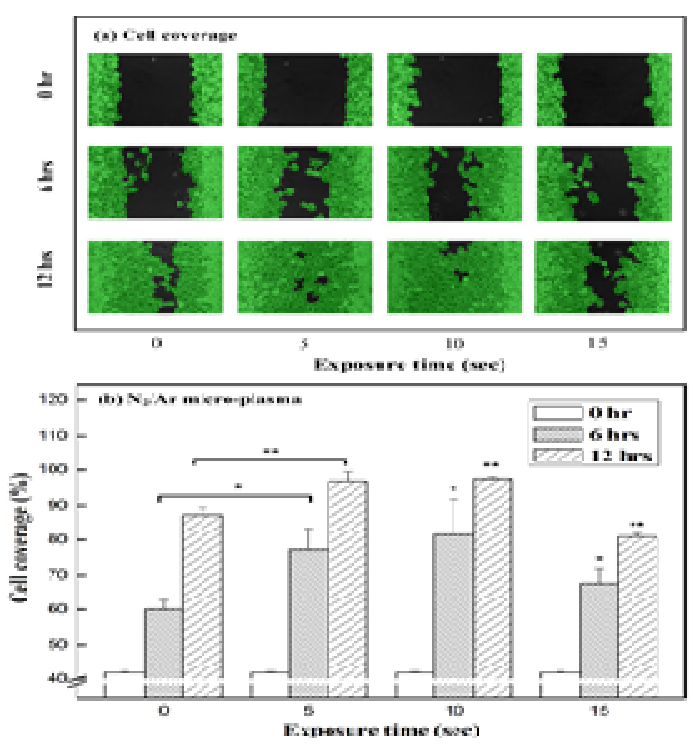

Figure 9: (a) The progression of cell migration or coverage, 6 and 12 hrs after plasma exposure times of 5, 10, and $15 \mathrm{sec}$, were recorded with an optical microscope and (b) plotted for statistical analyses. Error bars indicate the standard error of the mean for $\mathrm{n}=6$ independent experiments.

\subsection{Wound closure kinetics}

Figure 10(a) shows representative photographs for wound closure reductions on 0 , 7 , and $14 \mathrm{dw}$. Figure 10(b) shows the healing rates corresponding to the reductions of the open surface measured by taking the result of $0 \mathrm{dw}$ as $100 \%$.

The results indicate that the reductions of the open surface were significant for P5 and P5+D5 as compared with the control cases of NT and D5, respectively. For example, on $7 \mathrm{dw}$, the open surface of P5+D5 was reduced to $45.34 \pm$ $10.45 \%$, as compared with $87.68 \pm 14.64 \%$ for NT.

On $14 \mathrm{dw}$, the differences became much more significant. For example, the open surface of $\mathrm{P} 5+\mathrm{D} 5$ was reduced to $2.89 \pm 1.4 \%$, as compared with $17.02 \pm 0.09 \%$ for NT. The healing process completed on $18 \mathrm{dw}$ in NT and $14 \mathrm{dw}$ in P5+D5. On average, the wound of P5+D5 healed about 5 days earlier than that of the control group.

\section{CONCLUSION}

$\mathrm{N} 2 / \mathrm{Ar}$ micro-plasma with optimized parameters i.e., a supplied power of $17 \mathrm{~W}$ with working distance of $12 \mathrm{~mm}$ for in vitro study and $13 \mathrm{~W}$, a working distance of $4 \mathrm{~mm}$ for in vivo study, with an average temperature below $40^{\circ} \mathrm{C}$, and $0.5 \% \mathrm{~N} 2$ addition to Ar plasma to obtain RPS, was applied to a fibroblast cell-containing medium and 2nd degree burn wound in mice. As a result, the cells subsequent functions, such as viability, proliferation and migration were influenced by plasma composition, its exposure time, and incubation time. In particular, $0.5 \%$ $\mathrm{N} 2 /$ Ar micro-plasma with an exposure time of 5 or $10 \mathrm{sec}$ on fibroblast cells was suggested for realizing the stimulated cell functions. In vivo study showed that under optimized plasma exposure conditions, the wound contraction was five days earlier than that for the control group. The generated ROS/RNS signals, with the nitratenitrite-NO pathways, stimulate the burn wound healing process in mice, correlated with the angiogenesis and epithelialization processes. Based on these preliminary results, a microplasma device with a low operating temperature and an adjustable plasma composition, indirectly generated ROS/RNS signals showed the positive effect on wound healing process in both case in vitro and in vivo study. This bio-safety device would be a promising tool with regard to improve further pre-clinical treatment of wounds. 


\section{Nghiên cứu tác động của Micro-plasma trong chữa trị vết thương ở mức độ in vitro và in vivo}

- $\quad$ Ngô Thị Minh Hiền 1

- Huỳnh Quang Linh ${ }^{1}$

- Liao Jiunn Der ${ }^{2}$

- Nguyễn Như Sơn Thủy ${ }^{1}$

${ }^{1}$ Trường Đại học Bách Khoa, ĐHQG-HCM

${ }^{2}$ Đại học Quốc gia Cheng Kung

\section{TÓM TÁT:}

Bài báo nghiên cứu tác dụng của Micro-plasma trên tế bào fibroblast và vết bỏng độ hai ở chuột, để tìm hiểu tính tương hợ sinh học và an toàn của Micro-plasma trong chữa trị vết thương. Thông số tối ưu của micro-plasma được lựa chọn là $0.5 \%$ N2 đối với Argon plasma, điện thế $17 W$ và $13 W$ tương ưng với mức độ in vitro và in vivo. Microplasma được nghiên cứu đầu tiên trên tế bào fibroblast, kết quả cho thấy, số lượng tế bào fibroblast tăng gấp ba lần so với nhóm tế bào không được xử lý, đặc biệt với chiếu micro-plasma ở 5 và 10 sec. Mức độ dịch chuyển của tế bào tăng $20 \%$ so với nhóm không xử lý. Dựa trên những kết quả bước đầu trên tế bào, micro-plasma tiếp tục ứng dụng để chữa trị vết bỏng độ 2 ở chuột. Nghiên cứu cho thấy Micro-plasma đã thúc đẩy quá trình hàn gắn vết bỏng sơm hơn 5 ngày so với nhóm không được xử lý.

Từ khóa: Micro-plasma, tế bào fibroblast, sự tăng trưởng và dịch chuyển của tế bào, vết bỏng độ 2, tín hiệu ROS/RNS.

\section{REFERENCES}

[1]. S. Kalghatgi, G. Friedman, A. Fridman, A. M. Clyne, "Endothelial cell proliferation is enhanced by low dose non-thermal plasma through fibroblast growth factor-2 release", Annual Biomedical Engineering, 38, 3, 748757, 2010.

[2]. S. Kalghatgi, C. M. Kelly, E. Cerchar, B. Torabi, O. Alekseev, Fridman, A. G. Friedman, J. Azizkhan-Clifford, "Effects of Non-Thermal Plasma on Mammalian Cells", Plos One, 6, 1, e16270, 2011.

[3]. Y. Y. Huang, S. K. Sharma, J. Carroll, M. R. Hamblin, "Biphasic dose response in low level light therapy - an update", Dose Response, 9, 4, 602-618, 2011.

[4]. J. S. Knabl, G. S. Bayer, W. A. Bauer, I. Schwendenwein, P. F. Dado, C. Kucher, R. Horvat, E. Turkof, B. Schossmann, G. Meissl, "Controlled partial skin thickness burns: an animal model for studies of burnwound progression", Burns, 25, 3, 229235, 1999.

[5]. G. Fridman, G. Friedman, A. Gutsol, A. B. Shekhter, V. N. Vasilets, A. Fridman, "Applied plasma medicine", Plasma Processes Polymers, 5, 6, 503-533, 2008. 
[6]. S. A. Ermolaeva, O. F. Petrov, G. G. Miller, I. A. Shaginian, B. S. Naroditskii, E. V. Sysoliatina, A. Mukhachev, G. E. Morfill, V. E. Fortov, A. I. Grigor, "Prospects for the use of low-temperature gas plasma as an antimicrobial agent", Vestnik Rossiiskoi akademii meditsinskikh nauk / Rossiiskaia akademiia meditsinskikh nauk , 10, 15-21, 2011.

[7]. A. V. Nastuta, I. Topala, C. Grigoras, V. Pohoata, G. Popa, "Stimulation of wound healing by helium atmospheric pressure plasma treatment", Journal of Physics D: Applied Physics, 44, 10, 105204, 2011.

[8]. A. Fridman, A. Chirokov, A. Gutsol, "Nonthermal atmospheric pressure discharges", Journal of Physic D: Apply Physic, 38, 2, R1-R24, 2005.

[9]. D. Staack, A. Fridman, A. Gutsol, Y. Gogotsi, G. Friedman, "Nanoscale Corona Discharge in Liquids, Enabling Nanosecond Optical Emission Spectroscopy", Angew Chem Int Edit, 47, 42, 8020-8024, 2008. 